\title{
Isolation and characterization of Flavobacterium columnare (Bernardet et al. 2002) from four tropical fish species in Brazil
}

\author{
Pilarski, F. ${ }^{\mathrm{a} *}$, Rossini, $A \mathrm{~J}^{\mathrm{b} *}$ and Ceccarelli, PS. ${ }^{\mathrm{c} *}$ \\ ${ }^{a}$ Centro de Aquicultura, Universidade Estadual Paulista - UNESP, \\ Via de Acesso Prof. Paulo Donato Castellane, s/n, CEP 14884-900, Jaboticabal, SP, Brazil \\ bLaboratório de Saúde Animal, Universidade de São Paulo - USP, \\ Av. Duque de Caxias Norte, 225, CEP 13630-000, Pirassununga, SP, Brazil \\ ${ }^{\mathrm{c} C e n t r o ~ d e ~ P e s q u i s a ~ e ~ G e s t a ̃ o ~ d e ~ R e c u r s o s ~ P e s q u e i r o s ~ C o n t i n e n t a i s ~-~ C E P T A, ~}$ \\ Rod. Prefeito Euberto N. P. Godoy, s/n, Km 65, CEP 13630-970, Pirassununga, SP, Brazil \\ *e-mail: fabianap@caunesp.unesp.br, ajrosin@usp.br, paulo.ceccarelli@ibama.gov.br \\ Received August 17, 2006 - Accepted December 20, 2006 - Distributed May 31, 2008
}

(With 3 figures)

\begin{abstract}
Flavobacterium columnare is the causative agent of columnaris disease in freshwater fish, implicated in skin and gill disease, often causing high mortality. The aim of this study was the isolation and characterization of Flavobacterium columnare in tropical fish in Brazil. Piracanjuba (Brycon orbignyanus), pacu (Piaractus mesopotamicus), tambaqui (Colossoma macropomum) and cascudo (Hypostomus plecostomus) were examined for external lesions showing signs of colunmaris disease such as greyish white spots, especially on the head, dorsal part and caudal fin of the fish. The sampling comprised 50 samples representing four different fish species selected for study. Samples for culture were obtained by skin and kidney scrapes with a sterile cotton swabs of columnaris disease fish and streaked onto Carlson and Pacha (1968) artificial culture medium (broth and solid) which were used for isolation. The strains in the liquid medium were Gram negative, long, filamentous, exhibited flexing movements (gliding motility), contained a large number of long slender bacteria and gathered into 'columns'. Strains on the agar produced yellow-pale colonies, rather small, flat that had rhizoid edges. A total of four Flavobacterium columnare were isolated: 01 Brycon orbignyanus strain, 01 Piaractus mesopotamicus strain, 01 Colossoma macropomum strain, and 01 Hypostomus plecostomus strain. Biochemical characterization, with its absorption of Congo red dye, production of flexirubin-type pigments, $\mathrm{H}_{2} \mathrm{~S}$ production and reduction of nitrates proved that the isolate could be classified as Flavobacterium columnare.
\end{abstract}

Keywords: Flavobacterium columnare, Brazil, tropical fish, fish disease.

\section{Isolamento e caracterização de Flavobacterium columnare de quatro espécies de peixes tropicais no Brasil}

\section{Resumo}

Flavobacterium columnare é o agente etiológico da columnariose em peixes de água doce, ocasionando enfermidade na pele e nas brânquias, provocando freqüentemente um grande número de mortalidade. O objetivo deste estudo foi o isolamento e a caracterização de Flavobacterium columnare em peixes tropicais no Brasil. Piracanjuba (Brycon orbignyanus), pacu (Piaractus mesopotamicus), tambaqui (Colossoma macropomum) e cascudo (Hypostomus plecostomus) foram examinados externamente com relação a sinais característicos de columnariose, como manchas acinzentadas na cabeça, região dorsal e pedúnculo caudal dos peixes. A amostragem compreendeu a coleta de 50 exemplares de peixes, representando as quatro diferentes espécies escolhidas para este estudo. Amostras para o isolamento foram obtidas através de raspado com swab estéril das lesões e do rim dos peixes clinicamente diagnosticados como acometidos por columnarios e imediatamente semeados em meios de culturas artificiais (líquido e sólido) próprios para o estudo de Flavobacterium segundo Carlson e Pacha (1968). No meio líquido, houve o desenvolvimento de microrganismos que observados em gota pendente apresentaram a forma de bacilos finos, longos, móveis por deslizamento. Através da coloração de Gram, apresentaram morfologia de bacilos finos, Gram negativos, agrupados em colunas. Em meio sólido, as colônias eram pequenas, cinza-amareladas, com borda em forma de raiz. No total, foram obtidos quatro isolamentos: 01 cepa de Brycon orbignyanus; 01 cepa de Piaractus mesopotamicus; 01 cepa de Colossoma macropomum; e 01 cepa de Hypostomus plecostomus. A caracterização bioquímica das amostras, como absorção do vermelho Congo, produção de flexirrubina, produção de $\mathrm{H}_{2} \mathrm{~S}$ e redução do nitrato, sugere que os isolamentos poderiam ser classificados como Flavobacterium columnare.

Palavras-chave: Flavobacterium columnare, Brasil, peixes tropicais, doença de peixes. 


\section{Introduction}

Flavobacterium columnare the agent of columnaris disease was first described by Davis in 1922 as Bacillus columnaris and it was isolated by Ordal and Rucker (1944) and called Chondrococcus columnaris. It was subsequently called Flexibacter columnaris (Leadbetter, 1974), but in 1996 it was transferred to the genus Flavobacterium and was validated by publication in the International Journal of Systematic Bacteriology (Bernardet et al., 2002).

The ubiquitous distribution of the organism in fresh water environments and the tendency for fish to acquire the disease after mechanical and/or environmental insults makes $F$. columnare among the most described pathogens in cultured, ornamental and wild fish populations (Triyanto and Wakabayashi, 1999; Austin and Austin, 1999; Bader et al., 2003; Jinu and Goodwin, 2004). Epizootics of columnaris are rarely spontaneous and have been troublesome in hatcheries, pen, cage culture and in pond culture, particularly under adverse environmental conditions and factors stressful to the fish. These factors are correlated with rising water temperature, excessive foreign matter in the water, high stocking density or poor conditions (Wood and Yasutake, 1957; Wakabayashi, 1991; Kinnunen et al., 1997; Decostere et al., 1998) which cause enormous economic damage every year in many countries (Foscarini, 1989; Arias et al., 2004).

The columnaris disease is characterized by greywhite discoloration on some parts of the head, around the mouth, gills, fin or body. This is usually surrounded by a zone with a distinct reddish tinge, leading to under running of adjacent skin (Jeney and Jeney, 1995). Skin scraping or gill squash preparations from fish with cutaneous columnaris reveal large numbers of long, rodshaped bacteria arranged in columns or hay stacks (Newton et al., 1997).

Current methods for the precise identification of Flavobacterium involve lengthy procedures to define biochemical, morphological and cultural characteristics, such as its ability to grow on an isolation medium; colony color and morphology consistent with typical Flavobacterium; production of a diffusible gelatin degrading enzyme; binding of aqueous Congo red dye on the surface secretions of suspected colonies (Griffin, 1992; Jinu and Goodwin, 2004).

In Brazil, Ceccarelli et al. (1995) reported a serious outbreak of columnaris disease in various species from tropical fish but as far as we know, it has never actually been isolated and identified from tropical fish in Brazil. An accurate and prompt identification can ensure treatment and provide a valid basis for effective management decisions (Griffin, 1992). The objective of the present study is isolation and characterization of Flavobacterium columnare from four tropical fish species with typical lesions of disease based upon biochemical, morphological and cultural characteristics which have been reported elsewhere in the published literature.

\section{Material and Methods}

\subsection{Processing of fish for the collection of bacteriological samples}

Samples of skin and kidney (100 samples) were collected from 50 moribund fish from farms monitored by Welfare and Disease Control Laboratory of the CEPTA/IBAMA with fin rot and other skin lesions, such as greyish white spots, especially on the head and skin erosion of the back just in front of the caudal and dorsal fin were selected for this study (Figure 1). The fish species included 13 Piaractus mesopotamicus, 15 Colossoma macropomum, 12 Brycon orbignyanus (Valenciennes, 1850) and 10 Hypostomus plecostomus. All fish were collected alive and examined within 24 hours.

Fish collected were subjected to an extensive macroscopic examination to note the clinical health status. Mucus samples were obtained by skin scrape from the head, gills, caudal and dorsal fin and wet mount was used to determine motility in the hanging-drop method and Gram stain was used for determining the Gram reaction. The material was examined by a phase-contrast light microscopy. After this, pieces of skin and kidney samples were taken aseptically, with a swab directly from tissue which was exposed by a dorso-ventral crosscut into the body cavity with care taken to avoid cutting the gut. These samples were streaked onto broth or agar medium modified from Anacker and Ordal (1955), a non selective medium for the isolation of Gram negative gliding bacteria and incubated at $25^{\circ} \mathrm{C}$ for 48 hours and suspect colonies were selected for further analysis.

\subsection{Culture medium composition}

The medium utilized in the present study was a modification of those used by Anacker and Ordal (1955) for inducing the growing of other bacteria and limiting Flavobacterium growth. These modifications of the Anacker and Ordal medium (1955) were found to be very satisfactory for recovering Flavobacterium columnare. The modified medium was composed of peptone $\left(\right.$ Difco $\left.^{\circledR}\right), 3$ g.L L $^{-1}$, yeast extract (Fleishemann ${ }^{\circledR}$ ),

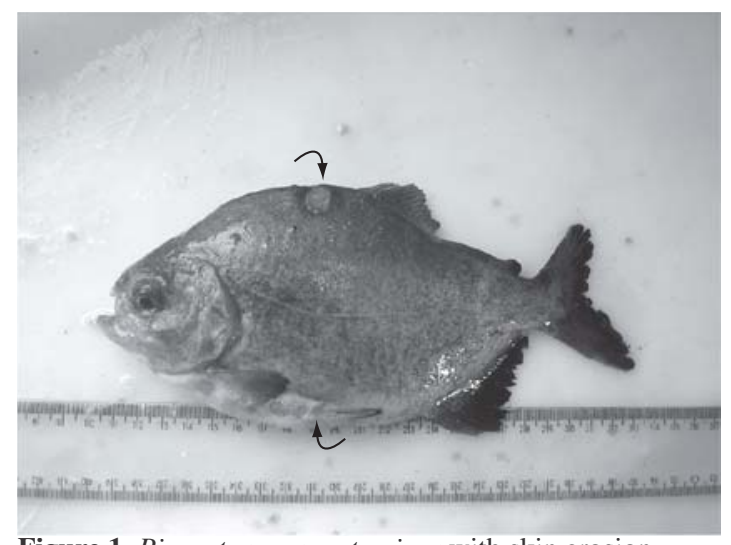

Figure 1. Piaractus mesopotamicus with skin erosion. 
5 mL.L ${ }^{-1}$, sodium acetate, 0.02 g.L. $\mathrm{L}^{-1}, \mathrm{NaCl}\left(\mathrm{Merck}^{\circledR}\right)$, 0.02 g.L $\mathrm{L}^{-1}$, fish peptone, $100 \mathrm{~mL} . \mathrm{L}^{-1}$ and agar $\left(\right.$ Difco $^{\circledR}$ ), 2.5 g. $\mathrm{L}^{-1}$. The $\mathrm{pH}$ was adjusted to 7.2 with $\mathrm{NaOH}$. The infusion of fish peptone was prepared with pieces of Oreochromis niloticus (Linnaeus, 1757) muscle and scale (approximately $15 \mathrm{~g}$ each) in $1000 \mathrm{~mL}$ of distilled water. Each piece of extracted muscle and scale was ground for twenty minutes and boiled for five minutes. The liquid was allonved to settle for thirty minutes and then filtered. The infusion was added to broth and solid media and autoclaved at $120^{\circ} \mathrm{C}$ for 15 minutes.

\subsection{Isolation of Flavobacterium columnare}

After the strains were grown in liquid medium for 48 hours, the characteristics were evaluated along with the appearance of the growth in liquid medium flask culture, morphology of Gram stained bacteria was observed under the microscope (magnification, x 100) and the typical flexing movements of the bacteria by using a hanging drop and light microscope (magnification, $x$ 40). Tenfold serial dilutions of each culture were made in phosphatebuffered saline, and $0.1 \mathrm{~mL}$ of each dilution was inoculated on five different Anacker and Ordal plates. All plates were incubated at $25{ }^{\circ} \mathrm{C}$ for 48 hours. After incubation, viable counts were made simultaneously on plates. The identification of the isolated Flavobacterium strain was checked on the basis of the characteristic yellow-green colonies, with rhizoid edges that contained Gram negative rods exhibiting gliding motility (Shamsudin and Plumb, 1996). After purification of colonies, the four isolates were identified using the criteria as described previously by Bernardet and Grimont (1989).

\subsection{The morphological and physiological studies}

Cellular morphology was determined by Gram stain and the bacterial cells were observed under a microscope (magnification, $x$ 100). Motility was determined on wet mounts under phase contrast microscopy (magnification, $40 \mathrm{x}$ ). The other tests used were: colony appearance and consistency, pigment production after exposing cultures to $\mathrm{KOH}(20 \%)$ solution. Gliding motility was checked under a microscope (magnification, $x$ 100) by using a hanging drop preparation of a 48 hours liquid medium culture. The presence of flexirrubin type pigments, Congo red absorption, catalase, DNAse, starch hydrolysis and gelatin liquefaction were all as described by Reichenbach et al. (1974). The presence of catalase was determined with hydrogen peroxide. Gelatin degradation was tested with the liquid medium supplemented with $0.4 \%\left(\right.$ w. $\mathrm{v}^{-1}$ ) gelatin which was flooded with acid mercuric chloride. Gelatin degradation was indicated when a local clearing was observed in the medium. Production of acid from glucose was determined using liquid medium supplemented with $0.4 \%$ dextrose. The starch hydrolysis was determined using medium containing a $0.2 \%\left(\mathrm{w}_{\mathrm{v}} \mathrm{v}^{-1}\right)$ solution of soluble starch on which colonies that hydrolyzed starch produced clear areas. Casein hydrolysis was determined with agar medium supplemented with $10 \%$ dry milk. The plates were flooded with $1 \% \mathrm{HCl}$ five days after inoculation, in which clear areas were indicative of proteolysis. Congo red absorption was assessed by flooding plates containing colonies with a $1.0 \%$ aqueous solution of Congo red for a few seconds, followed by rinsing with tap water. Colonies having a flexirubin type of pigment exhibit an immediate color shift from yellow or orange to red, purple or brown when flooded with $20 \% \mathrm{KOH}$ and revert to their initial color when flooded by an acidic solution (Bernardet et al., 2002). The ability to reduce nitrates was investigated in $0.1 \%$ potassium nitrate broth tubes (Bullock, 1972). The other biochemical tests were determined using an Enterobacteriaceae kit $\left(\operatorname{Laborclin}^{\circledR}\right)$

\section{Results}

\subsection{Isolation of Flavobacterium columnare strains from tropical fish}

From 50 samples, 04 strains of Flavobacterium columnare were isolated from kidney fish with ulcerated skin and discoloration on their caudal fin. Those isolated were: 01 Brycon orbignyanus strain, 01 Piaractus mesopotamicus (Holmberg, 1887) strain, 01 Colossoma macropomum (Cuvier, 1818) strain and 01 Hypostomus plecostomus (Linnaeus, 1758) strain. Four strains were designated K2, K3, K4 and K5. The optimal growth of the four strains occurred at $25{ }^{\circ} \mathrm{C}$, as reported by Decostere et al., (1998). All of the strains isolated were filamentous bacteria, Gram negative and filamentous bacteria exhibiting flexing movements (Figure 2).

The strains in wet mount exhibited flexing movements, contained a large number of long slender bacteria and were gathered into 'columns'.

In broth, all strains produced a pellicle as a ring at the medium glass interface. Filamentous tufts of bacteria adhered to the base and sides of the flasks and some tufts hung from the surface pellicle into the broth, producing a distinct fruity odor, as indicated by Shamsudin and Plumb, (1996).

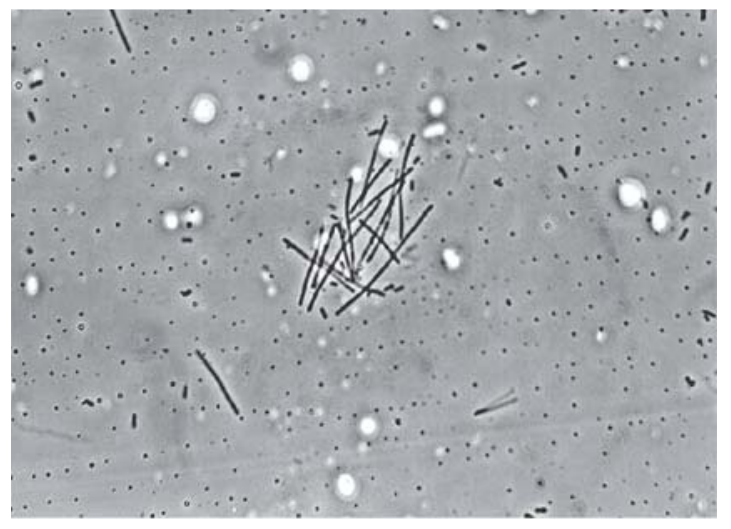

Figure 2. Wet mount strains (100x) of long bacilli Flavobacterium columnare isolates. 
On the agar, colonies were yellow-orange, flat, rather small and had irregular edges (rhizoid) but some colonies were more rhizoid than others and had different sizes and shapes, non-adherent to the agar (Figure 3), translucent, pale yellow due to flexirubin type pigments but the color was of different intensities on Anacker and Ordal agar as described by Bernardet and Grimont (1989). The properties varied among the four strains since the aspect of the colonies at the agar regular edges was a little rhizoid or a little spreading. F. columnare colonies were clearly visible after 48 hours.

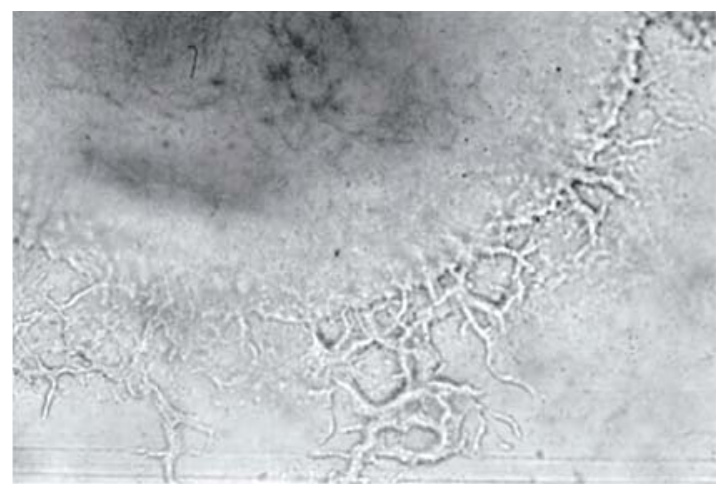

Figure 3. Light microscopy (40x) of Flavobaterium columnare colony onto Anacker and Ordal medium.

\subsection{Biochemical tests}

Biochemical characteristics of Flavobacterium columnare strains were identical and are given in Table 1.

All four strains reduced nitrate, a characteristic of Flavobacterium species observed by Bernardet and Grimont (1989) and the other 46 strains did not reducenitrate.

These colonial and biochemical characteristics of the bacterial test isolates are consistent with those of F. columnare (Reichenbach et al., 1974; Bernardet and Grimont, 1989; Griffin, 1992; Bernardet et al., 1996).

\section{Discussion}

There is scant information available on the actual occurrence, pathogenesis or severity of $F$. columnare in tropical fish. In the majority of the studies dealing with the disease, coldwater and temperate fish species (Decostere et al., 1998), nevertheless several species of gliding bacteria belonging to the Flavobacterium complex are known to be pathogenic to a wide range of freshwater fish and the most commonly reported pathogen is Flavobacterium columnare (Carson et al., 1993).

This bacteria has been reported in many parts of the world (Wakabayashi, 1991; Decostere et al., 1998; Bernardet, 1989) but this the first isolation of Flavobacterium columnare from tropical fish in Brazil and this isolation indicates the increasing significance of

Table 1. Biochemical characteristics of the Flavobacterium columnare strains isolated from tropical fish.

\begin{tabular}{|c|c|c|c|c|}
\hline Characteristics & Piracanjuba & Pacu & Tambaqui & Cascudo \\
\hline Gliding motility & + & + & + & + \\
\hline Pale yellow pigmented colonies & + & + & + & + \\
\hline L Tryptophane & + & + & + & + \\
\hline Glucose fermented & + & + & + & + \\
\hline Raffinose & - & - & - & - \\
\hline Citrate utilization & + & + & + & + \\
\hline Cytochrome oxidase & + & + & + & + \\
\hline Flexirrubin-type pigment & + & + & + & + \\
\hline Congo Red test & + & + & + & + \\
\hline DNA & + & + & + & + \\
\hline Nitrate reduction & + & + & + & + \\
\hline $\mathrm{H}_{2} \mathrm{~S}$ production & + & + & + & + \\
\hline Catalase & + & + & + & + \\
\hline Indole production & - & - & - & - \\
\hline Lysine decarboxylase & - & - & - & - \\
\hline Ornithine decarboxylase & - & - & - & - \\
\hline Starch hydrolysis & - & - & - & - \\
\hline Casein hydrolysis & + & + & + & + \\
\hline Gelatin hydrolysis & + & + & + & + \\
\hline Urea hydrolysis & + & + & + & + \\
\hline
\end{tabular}

(+) positive; (-) negative 
the Flavobacterium complex of bacteria as pathogens of farmed tropical fish (Ceccarelli et al., 1995).

Flavobacterium columnare was isolated from four tropical fish species and the phenotypie profile of four strains, identified in this study as Flavobacterium columnare, it is in agreement with the description given by Bernardet and Grimont (1989) and Decostere et al., (1998) for strains isolated in the United States and Europe.

A variety of media has been used to selectively isolate members of the genus Flavobacterium. Comparisons of the efficacy of the various selective mediums have, however, not been made. The isolation of Flavobacterium columnare in common medium is very difficult since the growth of the bacteria may be suppressed by other faster growing bacteria, by other bacteria which have extracellular products with cellulolytic or other antagonistic effects or by commensal bacteria, as shown by Chowdhury and Wakabayashi (1989) and Kinnunen et al., (1997).

The composition of the medium should give sufficiently good growth conditions for the strains to be isolated, but an ideal medium for Flavobacterium disease did not exist. The isolation of this bacteria in medium considered to be selective by many authors did not occur because the Flavobacterium colonies were often prevented by the growth of other bacteria thus, modifications of the Anacker and Ordal medium (1955) as the replacement of tryptone by peptone, beef extract by infusion of fish peptone and the increase of sodium chlored, which were found to be very satisfactory for isolation of Flavobacterium columnare, because these inorganic substances provided optimal growth for Flavobacterium (Shieh, 1980). The present results appear to be in conflict with those of Holmes et al. (1992), because we showed that Flavobacterium sp. grows poorly on nutrient media containing meat extract and peptone and the strains isolated in this study demonstrated good growth in meat fish and peptone.

The four strains isolated in this study were similar in size, shape and the gliding motility of bacteria. However, our strains differed from other reported strains in that they failed to adhere to agar, but Bernardet and Grimont (1989) suggested that strains were initially atypical Flavobacterium strains, but that later beame typical (lost their ability to produce rhizoid adherent colonies) through subcultivation. Other exceptions were: nitrate reduction is considered by most authors to be negative, but Wakabayashi et al., (1970) and Bernardet and Grimont (1989) found it to be positive, as we did. The most significant characteristics of this organism are that it: produces rhizoid flat yellow colonies on solid media, it reacts with the Congo red dye, produces flexirubintype pigments and $\mathrm{H}_{2} \mathrm{~S}$ and reduces nitrates (Bernardet and Grimont, 1989; Shamsudin and Plumb, 1996; Jinu and Goodwin, 2004).

The finding of Flavobacterium columnare in Brazil is significant in that this is the first report of this serious fish pathogen in this country namely because high water temperature was shown to be an important factor for the occurrence of external lesions with filamentous bacteria on fish and for increased mortality in the affected tanks and columnaris outbreaks occuring when the water temperature reaches $15^{\circ} \mathrm{C}$ (Wakabayashi, 1991) and water temperature in most parts of the Brazil is high with $15^{\circ} \mathrm{C}$. Morphological, physiological and biochemical characteristics clearly identify these strains as Flavobacterium columnare. However, additional studies are in progress to enhance the ability to isolate Flavobacterium in tropical fish farms.

Acknowledgements - The authors are indebted to the National Research Center of Tropical Fish (CEPTA/IBAMA) for providing fish isolates used in this study.

\section{References}

ANACKER, RL. and ORDAL. EJ., 1955. Study of a bacteriophage infecting the myxobacterium Chondrococcus columnaris. J. Bacteriol., vol. 70, no. 6, p. 738-741.

ARIAS, CR., WELKER, TL., SHOEMAKER, CA., ABERNATHY, JW., KLESIUS, PH., 2004. Genetic fingerprinting of Flavobacterium columnare isolates from cultured fish. J. App. Microbiology., vol. 97, no. 7, p. 421-428.

AUSTIN, B. and AUSTIN, DA., 1999. Bacterial fish pathogens: disease in farmed and wild fish. Chichester: Ellis Horwood. $364 \mathrm{p}$.

BADER, JA., SHOEMAKER, C.A., KLESIUS, PH., 2003. Rapid detection of columnaris disease in channel catfish (Ictalurus punctatus) with a new species-specifi 16-S rRNA gene-based PCR primer for Flavobacterium columnare. J. Micoriol. Methods, vol. 52, no. 2, p. 209-220.

BERNARDET, JF. and GRIMONT, PAD., 1989. Deoxyribonucleic acid relatedness and phenotypic characterization of Flexibacter columnaris sp. nov., nom. rev., Flexibacter psychrofilus sp. nov., nom. ver., and Flexibacter maritimus. Int. J. Syst. Bacteriol., vol. 39, no. 3, p. 346-354.

BERNARDET, JF., SEGERS, P., VANCANNEYT, M., BERTHE, M., KERTERS, K. and VANDAMME, P., 1996. Cutting a Gordian Knot: Emended classification and description of the genus Flavobacterium, emended description of the family Flavobacteriaceae, and proposal of Flavobacterium hydatis nom. nov. (basonym, Cytophaga aquatilis Strohl and Tait 1978). Int. J. Syst. Bacteriol., vol. 46, no. 1, p. 128-148.

BERNARDET, JF., NAKAGAWA, Y. and HOLMES, B., 2002. Proposed minimal standards for describing new taxa of the family Flavobacteriaceae and emended description of the family. Int. J. Syst. Evol. Micr., vol. 52, no. 3, p. 1049-1070. Available from: http://dx.doi.org/10.1099/ijs.0.02136-0. [Data de acesso 10/04/2003]

BULLOCK, GL., 1972. Studies on selected Myxobacteria pathogenic for fishes. US Dept Interior, Fish and Wildlife Service, Bureau of Sport Fisheries and Wildlife. Technical paper, vol. 60, no. 2, p. 4-19.

CARSON, J., SCHMIDTKE, LM. and MUNDAY, BL., 1993. Cytophaga johnsonae: a putative skin pathogen of juvenile farmed barramundi, Lates calcarifer. J. Fish Disease., vol. 16, no. 5 , p. 209-218. 
CECCARELLI, PS., FIGUEIRA, LB., FERRAZ DE LIMA, CLB., OLIVEIRA, C., 1995. Observações sobre a ocorrência de parasitos e bactérias de peixes no Cepta/Ibama entre 1983 a 1990. Boletim Técnico do Cepta, vol. 3, no. 6, p. 43-54.

CHOWDHURY, BR. and WAKABAYASHI, H., 1989. Effects of competitive bacteria on the survival and infectivity of Flexibacter columnaris. Fish Pathol., vol. 24, no. 1, p. 9-15.

DAVIS. HS., 1922. A new bacterial disease for freshwater fishes. U.S. Bureau of Fisheries Bulletin., vol. 38, no. 12, p. 261-280.

DECOSTERE, A., HAESEBROUCK, F. and DEVRIESE, LA., 1998. Characterization of four Flavobacterium columnare (Flexibacter columnaris) strains isolated from tropical fish. Vet. Microbiol., vol. 62, no. 1, p. 35-45.

FOSCARINI, R., 1989. Induction and development of bacterial gill disease in the eel (Anguilla japonica) experimentally infected with Flexibacter columnaris: pathological changes in the gill vascular structure and cardiac performace. Aquaculture, vol. 78 , no. 1, p. 1-20.

GRIFFIN, BR., 1992. A simple procedure for identification of Cytophaga columnaris. J. Aquat. Anim. Health., vol. 4, no. 2, p. 63-66.

HOLMES, B., OWEN, RJ. and MCMEEKIN, TA., 1992. Genus Flavobacterium. In BUCHANAN, RE. and GIBBONS, NE., editors. Bergey's manual of determinative bacteriology, $8^{\text {th }}$ ed. Baltimore, Maryland: Williams \& Wilkins.

JENEY, Z. and JENEY, G., 1995. Recent achievements in studies on diseases of Common carp (Cyprinus carpio). Aquaculture, vol. 129 , no. $1-4$, p. 397-420.

JINU, TS. and GOODWIN, E., 2004. Morphological and genetic characteristics of Flavobacterium columnare isolates: correlations with virulence in fish. J. Fish Diseases, vol. 27, no. 1, p. 29-35.

KINNUNEN, PR., BERNARDET, JF. and BLOIGU, A., 1997. Yellow pigmented filamentous bacteria connected with farmed salmonid fish mortality. Aquaculture, vol. 149, no. 1, p. 1-14.
LEADBETTER, ER., 1974. Flexibacter. In BUCHANAN, RE. and GIBBONS, NE., editors. Bergey's manual of determinative bacteriology, 8 th edition. Baltimore, Maryland: Williams and Wilkins.

NEWTON, JC., WOOD, TM. and HARTLEY, MM., 1997. Isolation and partial characterization of extracellular proteases produced by isolates of Flavobacterium columnare derived from channel catfish. J. Aquat. Anim. Health, vol. 9, no. 2, p. 75-85.

ORDAL, EJ. and RUCKER, RR., 1944. Pathogenic myxobacteria. Proc. Society Exp. Biol. Medicine, vol. 56, no. 1, p. $15-18$.

REICHENBACH, H., KLEINING, H. and ACHENBACH, H., 1974. The pigments of Flexibacter elegans: novel and chemosystematically useful compounds. Arch. Microbiol., vol. 101, no. 2, p. 131-144.

SHAMSUDIN, MN. and PLUMB, JA., 1996. Morphological, biochemical and physiological characterization of Flexibacter columnaris isolates from four species of fish. J. Aquat. Anim. Health, vol. 8, no. 4, p. 335-339.

SHIEH, HS., 1980. Studies on the nutrition of a fish pathogen, Flexibacter columnaris. Microbios Lett., vol. 13, no. 51-52, p. 129-133.

TRIYANTO, AK., WAKABAYASHI, H., 1999. Genotypic diversity of strains of Flavobacterium columnare from diseased fishes. Fish Pathol., vol. 34, no. 2, p. 65-71.

WAKABAYASHI, H., 1991. Effects of environmental conditions on the infectivity of Flexibacter columnaris to fish. J. Fish Diseases, vol. 14, no. 3, p. 279-290.

WAKABAYASHI, H. and EGUSA, S., 1970. Studies on columnaris disease of pond-cultured eel - I. Characteristics and pathogenicity of Chondrococcus columnaris isolated from pond-cultured eels. Bull. Jpn. Soc. Scientific Fisheries, vol. 36, no. 2, p. 147-155.

WOOD, EM. and YASUTAKE, WT., 1957. Histopathology of fish (Gill disease). Progres. Fish. Cult., vol. 19, no. 1, p. 7-13. 